\title{
Evaluation of Selected Properties of Alder Wood as Functions of Sanding and Coating
}

\author{
Emilia-Adela Salca ${ }^{1, *}$, Tomasz Krystofiak ${ }^{2}$ and Barbara Lis ${ }^{2}$ \\ 1 Faculty of Wood Engineering, Transilvania University of Brasov, Universitatii 1, 500068 Brasov, Romania \\ 2 Faculty of Wood Technology, Poznan University of Life Sciences, Wojska Polskiego 28, 60-637 Poznan, \\ Poland; tomkrys@up.poznan.pl (T.K.); blis@up.poznan.pl (B.L.) \\ * Correspondence: emilia.salca@unitbv.ro; Tel.: +40-268-415-315
}

Academic Editor: Mojgan Nejad

Received: 31 August 2017; Accepted: 20 October 2017; Published: 21 October 2017

\begin{abstract}
The objective of this study was to optimize the sanding and coating processes of black alder wood to promote and support its use in furniture manufacturing. Two criteria have been applied for process optimization, namely, the minimum surface roughness of the samples and power consumption during sanding as a function of various sanding systems. The surface roughness of the sanded specimens and the power consumption during sanding strongly depends on the grit size used. Two eco-varnishes were applied to the samples by spraying. Moreover, the effect of the surface preparation and varnish type on the coating properties expressed by the varnish layer adherence to the substrate and surface glossiness was evaluated. For better glossiness values, the UV-cured varnish was preferred. The sanding with a grit sequence of 60,120 , and 150 grit size abrasives was found to be optimal when applied to black alder wood, and it is recommended to obtain performant UV-coated wood surfaces for furniture products.
\end{abstract}

Keywords: black alder; coating; roughness; processing; varnish

\section{Introduction}

The furniture industry has been rapidly developing and diversifying. It strongly leads to the implementation of a certain strategy shift from a traditional business model to a model based on value generation. Such an approach was supported by the competitive advantage of qualitative, innovative, and ecological products that are differently granted when compared to other products [1]. Furniture units manufactured from wood-based materials are very common on the market, but solid wood furniture still keeps its popularity. When compared to composites, attributes such as reliability, environment-friendliness, good looks, and value are used to describe solid wood [2]. Each piece of wood needs to experience a long process until it reaches the most appropriate state for interior design. Sanding is considered an important process prior to finishing in furniture manufacturing, among others. The product quality is influenced by rational and optimal fabrication based on some specific technologies. To implement such optimization, two certain criteria should be simultaneously fulfilled, namely, having the best surface quality and the best cutting performance [3,4]. Several factors of the wood-machine-tool interaction influence the surface quality through the machining process during sanding, including properties of species, density, and moisture content, as well as cutting parameters such as pressure, belt speed, feed speed, cutting depth, processing direction, abrasive tools [5-10], cutting force, and power consumption [4,11].

Usually a sanding process starts with a rough grit size used for a rapid and deep sanding and then finer grit sizes are applied for the final finishing phases, to achieve a homogeneous substrate for subsequent coating applications [12]. 
The substrate preparation prior to the varnish application and the coating product present a specific influence on the properties of the final finished product [13]. The wood grain may raise, twist, and lift during the wetting and sanding, which can be reduced with a proper sanding process [14]. A rough surface produces an increase of the mechanical interlocking area between the coating and wood, while the adherence of varnish to the wood surface is reduced by the increase of wood equilibrium moisture content $[15,16]$. Gloss is one of the parameters used to assess the final quality of a product; it is mainly influenced by the chemical composition of the coating, but also by the substrate preparation $[17,18]$. Varnishes present different levels of gloss depending on their type and application system. It was shown that polyurethane and polyacrylic resins retained a high gloss even under thermal stress conditions, while for powder coatings a low gloss level was found [19].

The wood coating industry currently faces the influence of environmental regulations. Therefore, a clear focus on water-borne systems, high solids, UV-cured coating, and powder coating is recognized in the furniture sector. Interior coatings should be carried out with respect to the VOC (Volatile Organic Compounds) regulations, to present abrasion and chemical resistance and to have a high gloss effect [20]. In the case of exterior woodwork, the focus is on durability and protection against humidity, sunlight, and microbiological attack. It was found that modifications applied to the coating material or the substrate can significantly improve the performance of exterior clear coatings [21-23].

Several studies on coating properties were mostly performed for cellulose varnishes, solvent-borne or water-borne, which have been applied to different wood materials $[13,24]$. Such coating applications are common mostly for indoor furniture purposes. For humid areas, such as for kitchen and bath cabinets, vinyl wrap has been used, but water-borne and UV varnish products are expected to be applied instead [20]. Water-based coatings and UV-cured technologies are considered efficient solutions for wood coating operations $[25,26]$.

There is great potential in the wood furniture sector in Romania, considering that the furniture production export rate increased from $57.6 \%$ in 2008 to $86 \%$ in 2016 [27]. The market is mature and the consumers have started to inform themselves and behave as in the Western culture. Such aspects in furniture production were supported by the residential market, which was revived through the construction of large districts, and thus general consumption was encouraged [27].

Small- and medium-sized furniture manufacturing companies mostly use wood-based materials in their production line, but also use various local species, such as oak, ash, and cherry, in addition to other common hardwood species. Black alder wood (Alnus glutinosa L.) is a native species in Romania and could have potential as a raw material for furniture manufacturing companies. Black alder wood, which is an under-utilized species, also presents potential for furniture manufacturing, based on its great workability and properties. Due to its pleasant appearance, alder wood can also be successfully used as substitute for valuable species in various art restoration works.

Therefore, the objective of this original case study was to optimize the sanding and coating processes of black alder wood to promote and support its use in furniture manufacturing. Findings of this study may have brief industrial applications to achieve value-added furniture products.

\section{Materials and Methods}

Experiments were carried out with black alder (Alnus glutinosa L.) wood, a diffuse-porous species that is not commonly used for furniture products in Romania. A total of 20 flat sawn boards supplied by a local sawmill were planed and then cut at dimensions of $300 \mathrm{~mm} \times 6 \mathrm{~mm} \times 95 \mathrm{~mm}(L \times R \times T)$. The samples had an average basic density of $520 \mathrm{~kg} / \mathrm{m}^{3}$ and a moisture content of $8 \%$. Prior to their surface preparation, the samples were divided into four groups, each one of five samples, and conditioned in a room with a temperature of $20 \pm 2{ }^{\circ} \mathrm{C}$ and relative humidity of $50 \% \pm 5 \%$.

\subsection{Surface Preparation of the Samples by Sanding}

The sanding of the samples was performed under industrial conditions on a wide belt-sander machine (Timesavers, Inc., Maple Grove, MN, USA) with the following technical characteristics: 
abrasive belt dimensions of $1900 \mathrm{~mm} \times 1130 \mathrm{~mm}$, sanding speed (against the feed direction) of $16 \mathrm{~m} / \mathrm{s}$, contact pressure of $4.5 \mathrm{bar}$, and feed speed ranging from 4 to $20 \mathrm{~m} / \mathrm{min}$. The specimens were first subjected to calibration with a 60 grit size abrasive. Four parallel sanding systems were then applied by employing various grit size abrasives manufactured of corundum grains, such as $80,100,120$, and 150 grit sizes (SIA Abrasives Industries AG, Frauenfeld, Switzerland). The sanding sequences applied per group of samples are presented in Table 1. The calibration step and each individual sanding sequence were performed with the same cutting parameters, such as the feed speed of $12 \mathrm{~m} / \mathrm{min}$ and cutting depth of $0.3 \mathrm{~mm}$.

Table 1. Design of wood surface preparation by parallel sanding.

\begin{tabular}{ccccc}
\hline \multirow{2}{*}{$\begin{array}{c}\text { Sanding Sequence } \\
\text { and Grit Size }\end{array}$} & $\mathbf{8 0}$ & $\mathbf{1 0 0}$ Calibration C 60 & $\mathbf{1 2 0}$ & $\mathbf{1 5 0}$ \\
& $\mathbf{1 5 0}$ & $\mathbf{1 5 0}$ & $\mathbf{1 5 0}$ & \\
\hline Sanding System & No.1 (C, 80, 150) & No.2 (C, 100, 150) & No.3 (C, 120, 150) & No.4 (C, 150) \\
\hline
\end{tabular}

\subsection{Determination of the Power Consumption during Sanding}

An electronic device with two SINEAX P530/Q5431-type decoders (Camille Bauer Ltd., Wohlen, Switzerland), for cutting and feed, connected to the sander control board and an ADC-11 acquisition board (Pico Technology Ltd., Saint Neots, UK) was employed to record the power, at the millisecond scale, for each individual sanding step. The difference between such recordings and the power during idle running was considered the effective consumed power.

\subsection{Surface Roughness Measurement of the Samples}

Surface quality measurements were performed using a MicroProf FRT instrument (Fries Research \& Technology $\mathrm{GmbH}$, Bergisch Gladbach, Germany). A range of roughness parameters was calculated, such as the arithmetic mean deviation of the assessed profile $\left(R_{\mathrm{a}}\right)$ and the total height of the profile $\left(R_{\mathrm{t}}\right)$ from ISO 4287 standard [28] and the core roughness depth $\left(R_{\mathrm{k}}\right)$ and the reduced peak height $\left(R_{\mathrm{pk}}\right)$ from ISO 13565-2 standard [29]. The reduced valley depth $\left(R_{\mathrm{vk}}\right)$ from $R_{k}$ family was excluded from the evaluation because the anatomical roughness was not removed [30]. All parameters were measured in the 2D profile, perpendicular to the sanding direction, with a view to provide enough wood anatomical variation for evaluation. The scanning parameters were set according to the recommendations from the specialty literature [30]. Therefore, along an evaluation length of $50 \mathrm{~mm}$, having a sampling length of $2.5 \mathrm{~mm}$, with a measuring resolution of $5 \mu \mathrm{m}$, at the scanning speed of $750 \mu \mathrm{m} / \mathrm{s}$, a total of 10,000 points were scanned per measurement. A Gaussian filter was automatically applied to all roughness data. The roughness measurements were performed for all samples per sanding stage prior to coating.

\subsection{Coating of the Samples}

Two types of varnish, namely UV varnish and a water-borne (WB) varnish were applied to the samples after their surface preparation by sanding. To apply the varnish products on the samples, an industrial low-pressure spray gun at a pressure of 0.25 bar at a spread rate of $120 \mathrm{~g} / \mathrm{m}^{2}$ was used. The spraying was carried out in a laboratory under controlled conditions of the working environment $\left(20{ }^{\circ} \mathrm{C}\right.$ and $\left.40 \% \mathrm{RH}\right)$. All samples were coated with two layers, and a light sanding of 220 grit size abrasive was applied between the finishing steps to obtain a smooth surface. Two samples per sanding system group and varnish type were used for coating. One control sample per group was kept as a reference. The parameters of the coating products are presented in Table 2. 
Table 2. Parameters of the coating products.

\begin{tabular}{ccccccc}
\hline $\begin{array}{c}\text { Varnish } \\
\text { Code }\end{array}$ & $\begin{array}{c}\text { Varnish } \\
\text { Type }\end{array}$ & $\begin{array}{c}\text { VOC-EU (Volatile } \\
\text { Organic } \\
\text { Compounds), g/L }\end{array}$ & $\begin{array}{c}\text { Density } \\
\left(\mathbf{g} / \mathbf{c m}^{\mathbf{3}}\right) \mathbf{2 0} \mathbf{2 0}^{\circ} \mathbf{C}\end{array}$ & $\begin{array}{c}\text { Conventional } \\
\text { Viscosity (s), } \\
\mathbf{2 0}{ }^{\circ} \mathbf{C}[31]\end{array}$ & $\begin{array}{c}\text { Organic } \\
\text { Solvents (\%) }\end{array}$ & $\begin{array}{c}\text { Solid } \\
\text { Content (\%) }\end{array}$ \\
\hline 1 & $\begin{array}{c}\text { UV acrylic } \\
\text { water-borne }\end{array}$ & 55.2 & 1.229 & 42 & 6.5 & 93.5 \\
2 & (WB) & 55.2 & 1.024 & 65 & 5.4 & 27.9 \\
\hline
\end{tabular}

The curing process was performed separately as a function of the varnish type. Therefore, a UVC-250x2-type UV curing system (MIKON UV Ltd., Warsaw, Poland) was used to cure the samples coated with the UV varnish product, while the samples coated with the water-borne varnish product were cured at a room temperature of $20^{\circ} \mathrm{C}$ and $40 \% \mathrm{RH}$. The dry film thickness was only determined for both types of varnish products according to the specialty literature [32]. Thus, for the UV acrylic and water-borne varnish, the dry film thicknesses had the values of about $90 \pm 5 \mu \mathrm{m}$ and $30 \pm 5 \mu \mathrm{m}$, respectively.

\subsection{Adhesion Test of the Coatings}

The measurements of the coating adherence were performed in ambient conditions $\left(20^{\circ} \mathrm{C}\right.$ and $40 \% \mathrm{RH}$ ) by the pull-off test with the help of the PosiTest-AT adhesion tester (DeFelsko Corporation, Ogdensburg, NY, USA), in accordance with the ISO 4624 standard [33]. A two component silane-epoxy resin of Jowat 690.00 type was used to glue small steel dollies with $20 \mathrm{~mm}$ diameters on the film surface. After one week of curing, incisions were made around the dollies in order to prevent failure damages close to the tested area. The adhesion strength was recorded by the PosiTest device, which involves the vertical withdrawal of the cylinders with a constant detachment speed. Five measurements were taken from each coated sample. The delamination effect was visually assessed for each coated sample.

\subsection{Glossiness Measurement of the Samples}

A PICO GLOSS 503 gloss meter (ERICHSEN GmbH, Hemer, Germany) was employed to measure the glossiness of the control and coated samples in accordance with the ISO 2813 standard [34]. Five gloss measurements were conducted at a degree level of $60^{\circ}$, in both orientations perpendicular and parallel to the wood grain.

\subsection{Processing of the Data}

Picolog and Acquire Mark III software (Version 3.8) were employed to process the raw data for power and roughness recordings, respectively. Minitab 18.1 software was used to conduct the statistical analysis of data.

\section{Results and Discussion}

\subsection{Variation of Power Consumption and Evaluation of Surface Roughness after Sanding}

The power consumption and the surface roughness of the samples after each individual and final sanding step were determined. Such data were used to evaluate and to select the optimal surface preparation system prior to the coating application. The results are illustrated in Figure 1. The wood industry sector does not belong to the list of the highest power industrial consumers, but the sanding process of wood is considered to consume the most among all the processing steps. It was proven that the power consumed for sanding the wood increased with the belt speed and the feed speed, while a low variation was noticed for the increase of the cutting depth [3,4]. A light cutting depth can sometimes provide low sanded areas, while an overly high cutting depth may lead to belt wear, increased power consumption, and a low surface quality [30]. 


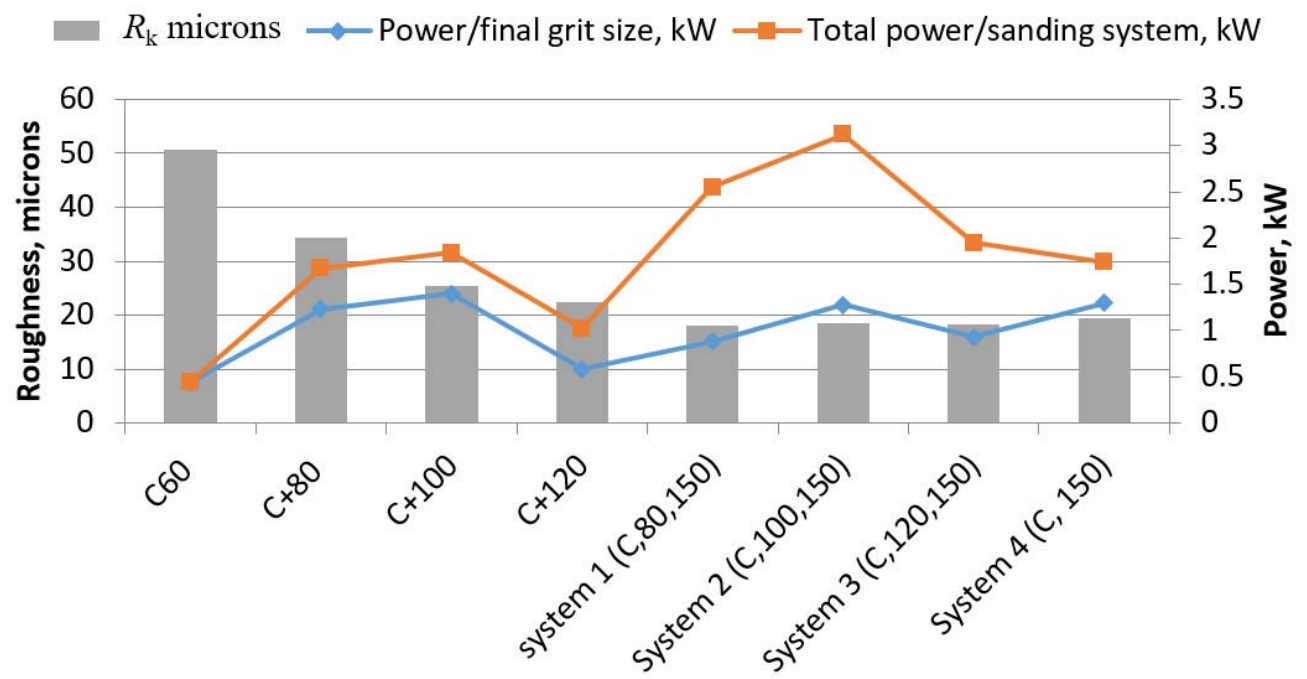

Figure 1. Variation of power consumption and processing roughness during sanding per each final grit size and total power per sanding system.

In this study, the cutting schedule was kept constant and the variation of power consumption was evaluated as a function of the grit size used for each individual and final sanding step. Therefore, an increase in the power consumption with the grit size for 80 and 100 grit size abrasives after calibration from 1.23 to $1.4 \mathrm{~kW}$ was determined. Overall power consumption increased with the decrease of grit size diameter for both approaches, such as the individual grit size step and final sanding, respectively. An exception was found in case of 120 grit size after calibration. In case of the total power consumption per sanding system, the highest value of $3.12 \mathrm{~kW}$ was obtained for the second system, while for the last two sanding systems (No. 3 and No. 4), a decreased trend was noticed.

The results of the roughness measurement of the samples are given in Table 3. The values of all the roughness parameters followed the same decreasing trend with the increase of the abrasive grit size. After sanding with 60 and 80 grit sizes, the maximum values obtained for $R_{\mathrm{k}}$ roughness parameter (ranging between 50 and 40 microns) were similar to those obtained by Gurau [30] for oak wood (40.5 microns) for the sanding with 60 grit size. Low density species have more fuzziness on their surfaces compared to the high density species [30]. Moreover, a tangential wood surface may contain either large or narrow areas of earlywood and latewood, which explains the large variation of the obtained results when sanding with course grit size abrasives [30]. At the same grit size, hard wood species present better quality surfaces compared to soft wood species. It is also a fact that the wood surface roughness is inversely proportional with wood density, which plays a much more important role than the species anatomy [30]. Other studies proved that the wood grain orientation is not significant for grit sizes such as 60,80 , and 100, but starts to be significant for grit sizes over 120 [7]. Abrasives of 60 and 80 grit sizes produce a crushed wood layer on the surface; thus, the wood tissue is forced to enter the cavities and therefore produces their obstruction. As a result, when using low feed speeds, the wood cells that remain uncut are blunt and bent, generating a better roughness, while for high feed speeds, some peaks are formed but they are considerably attenuated for finer grit sizes when applied at light feed speed [30]. In practice, such surfaces are subjected to successive sanding steps with 100,120,150, or 180 grit size abrasives, depending on their destination and further coating application system. The $R_{\mathrm{k}}$ and $R_{\mathrm{pk}}$ roughness parameters presented values over 20 microns, and 15 microns, respectively, which still highlighted a rough surface. Similar results were obtained by de Moura and Hernandez for maple wood when 100 grit size abrasive was applied [35]. $R_{\mathrm{pk}}$ roughness parameter gives a measure of the magnitude of raised fibers above the core roughness expressed by the $R_{\mathrm{k}}$ parameter [30]. 
Table 3. Average values of surface roughness per each intermediate sanding sequence and final sanding system.

\begin{tabular}{ccccc}
\hline Processing Step & $\boldsymbol{R}_{\mathbf{a}}$ (microns) & $\boldsymbol{R}_{\mathbf{t}}$ (microns) & $\boldsymbol{R}_{\mathbf{k}}$ (microns) & $\boldsymbol{R}_{\mathbf{p k}}$ (microns) \\
\hline Calibration (C) 60 & $16.5(2.6)^{*}$ & $230.3(80.4)$ & $50.6(5.6)$ & $29.4(20.6)$ \\
C + 80 & $11.2(1.4)$ & $165.0(51.1)$ & $34.3(4.1)$ & $21.7(10.4)$ \\
C + 100 & $8.5(1.0)$ & $138.1(30.8)$ & $25.3(1.8)$ & $15.2(6.8)$ \\
C + 120 & $7.7(1.3)$ & $118.0(33.7)$ & $22.5(3.9)$ & $11.8(5.7)$ \\
system No.1 (C, 80, 150) & $6.0(0.4)$ & $86.0(23.0)$ & $18.1(1.4)$ & $10.4(2.8)$ \\
System No.2 (C, 100, 150) & $6.03(0.8)$ & $87.6(37.4)$ & $18.6(2.2)$ & $8.5(2.3)$ \\
System No. 3 (C, 120,150) & $6.1(0.6)$ & $127.2(28.8)$ & $18.4(1.3)$ & $10.7(3.3)$ \\
System No. 4 (C, 150) & $6.2(0.9)$ & $100.9(21.1)$ & $19.4(2.4)$ & $9.1(3.5)$ \\
\hline
\end{tabular}

${ }^{*}$ Numbers in parenthesis are standard deviation values.

For alder wood sanded with 120 grit size paper, an average value of about 7.7 microns was found for the $R_{\mathrm{a}}$ roughness parameter, while for birch wood under the same sanding sequence, Vitosyte et al. [36] found lower values of about 5.14 microns. It appeared that the final sanding with 150 grit size for all four sanding systems generated surfaces described by similar values of the roughness parameters. Considering the two criteria for process optimization, it was found that that the sanding system No. 3 was optimal for producing better surface quality along a reduced value of power consumption.

\subsection{Evaluation of the Coating Properties}

Table 4 presents the results for the coating performance of the samples expressed by the adhesion strength and surface glossiness as a function of the sanding system applied and varnish type product.

Table 4. Average values of adherence and gloss at $60^{\circ}$ as a function of the sanding system and varnish type.

\begin{tabular}{ccccc}
\hline Sanding System & Varnish Type & Adherence (MPa) & Gloss 60 II & Gloss 60 $\neq$ \\
\hline \multirow{2}{*}{ No. 1 } & Uncoated & - & $3.1(0.1)^{*}$ & $2.2(0.1)$ \\
\cline { 2 - 5 } & UV & $1.41(0.02)$ & $35.6(3.8)$ & $19.9(2.2)$ \\
\cline { 2 - 5 } & WB & $1.20(0.01)$ & $27.6(3.8)$ & $18.2(2.3)$ \\
\cline { 2 - 5 } No. 2 & Uncoated & - & $2.5(0.2)$ & $2.0(0.1)$ \\
\cline { 2 - 5 } & UV & $1.29(0.1)$ & $26.5(11.8)$ & $17.5(4.1)$ \\
\cline { 2 - 5 } No. 3 & WB & $1.24(0.01)$ & $31.9(3.3)$ & $21.3(2.7)$ \\
\cline { 2 - 5 } & Uncoated & - & $2.8(0.2)$ & $2.1(0.1)$ \\
\cline { 2 - 5 } & UV & $1.22(0.01)$ & $42.5(2.2)$ & $27.0(2.4)$ \\
\hline \multirow{2}{*}{ No. 4 } & Uncoated & $1.22(0.2)$ & $25.8(3.5)$ & $16.8(1.7)$ \\
\cline { 2 - 5 } & UV & $1.39(0.1)$ & $2.8(0.1)$ & $2.1(0.1)$ \\
\cline { 2 - 5 } & WB & $1.43(0.1)$ & $24.5(4.8)$ & $15.0(0.9)$ \\
\hline
\end{tabular}

${ }^{*}$ Numbers in parentheses are standard deviations values.

The pull-off test failures of the specimens were found mostly in the wood layer as well as the varnish film. The samples were evaluated and destructions were found mostly in the substrate, while delamination between the adhesive and varnish was rarely observed. Alder wood is a low density diffuse porous wood species, and its structure allows good coating penetration. It is also a fact that good wetting provides a good film performance [37]. The highest values of adherence of about 1.39 MPa and 1.43 MPa for the samples sanded with system No. 4 were obtained for both varnish products. Such samples presented rough surfaces when compared to other substrate preparations. 
As expected, for rough surfaces, both varnish products adhered to the wood [38]. Generally, in terms of adherence, small differences were found when comparing the two varnish products. Results of other studies revealed that water-based finishes induced greater surface roughness, increasing the contact area and thus resulting in a better adherence to the wood surface [13,35].

The glossiness for $60^{\circ}$ geometry was determined for all of the samples both along the grain orientation and perpendicular to it. It is a fact that the surface quality influences the glossiness of the wood surface, part of its ability to reflect the light $[39,40]$. Generally, the gloss values for both directions of measurement were found to be higher for the samples coated with the UV varnish compared to the water-borne product. In case of UV-cured coating products, the varnish layer structure is enhanced. Results in the same range were obtained for beech samples previously sanded with a sanding sequence of 80 and 150 grit size abrasives and then coated with water-based coating, as reported by Slabejova [18].

Previous studies revealed that water-borne varnishes adversely affect the smoothness of the surface and, as a result, reduce the glossiness [15,39].

One-way ANOVA analysis (Table 5) showed that the coating performance expressed by the adhesion strength and glossiness at $60^{\circ}$ geometry was significantly influenced by the varnish type ( $p$-value $\leq 0.05$ ). The sanding systems used in the present study produced surfaces described by similar values of the roughness parameters, therefore, it was expected to have no relevant influence in terms of adherence for both two varnishes. But higher values of the adhesion strength were found in case of UV varnish, compared to water-borne varnish when only applied on surfaces sanded by the system No. 1 (C, 80,150). While, in case of other sanded surfaces, small or no differences were noticed between the two varnishes. In terms of glossiness no clear trend was observed as a function of the sanding system but the surfaces coated with UV varnish presented higher gloss when compared to the surfaces coated with the water-borne varnish product.

Table 5. One-way ANOVA analysis of adherence and gloss as a function of the sanding system and varnish.

\begin{tabular}{ccccccc}
\hline $\begin{array}{c}\text { One-Way ANOVA } \\
\text { Response }\end{array}$ & Source/Factor & $\begin{array}{c}\text { Degrees of } \\
\text { Freedom (DF) }\end{array}$ & $\begin{array}{c}\text { Adjusted Sums of } \\
\text { Squares (Adj SS) }\end{array}$ & $\begin{array}{c}\text { Adjusted Mean } \\
\text { Squares (Adj MS) }\end{array}$ & $\boldsymbol{F}$-Value & $\boldsymbol{p}$-Value \\
\hline \multirow{2}{*}{ Adherence, $\mathrm{MPa}$} & Sanding system & 3 & 0.1324 & 0.04415 & 0.11 & 0.956 \\
& Varnish type & 2 & 22.6216 & 11.3108 & 725.04 & 0.000 \\
\hline \multirow{2}{*}{ Gloss 60 II } & Sanding system & 3 & 87.8 & 29.28 & 0.12 & 0.946 \\
& Varnish type & 2 & 11620 & 5810.09 & 191.78 & 0.000 \\
\hline \multirow{2}{*}{ Gloss 60 $\neq$} & Sanding system & 3 & 37.53 & 12.51 & 0.14 & 0.933 \\
& Varnish type & 2 & 4337.2 & 2168.60 & 225.76 & 0.000 \\
\hline
\end{tabular}

Two criteria were applied to choose the optimal sanding system, namely, the minimum power consumption and the best surface quality. To continue the optimization, the response optimization for adherence and gloss as a function of the sanding system and varnish type was provided by Minitab software (Version 18.1) (Table 6). The result shows that the sanding system No. 3 is optimal, when considering the processing energy costs and the best surface quality along the maximum glossiness of the coating obtained for the UV varnish, even for a reduced coating adherence. In practice, high gloss is required for the visible parts of furniture more than for others. Such sanding with a grit sequence of 60,120 , and 150 grit size abrasives is usually used under industrial practice. Thus, it is also recommended for black alder wood to obtain final UV-coated wood surfaces for value-added products in furniture manufacturing.

Table 6. Response optimization for adherence and gloss as a function of sanding system and varnish type.

\begin{tabular}{ccccccc}
\hline Solution & $\begin{array}{c}\text { Varnish } \\
\text { Type }\end{array}$ & $\begin{array}{c}\text { Sanding } \\
\text { System }\end{array}$ & Gloss 60 F Fit & $\begin{array}{c}\text { Gloss 60 II } \\
\text { Fit }\end{array}$ & $\begin{array}{c}\text { Adherence } \\
\text { (Mpa) Fit }\end{array}$ & $\begin{array}{c}\text { Composite } \\
\text { Desirability }\end{array}$ \\
\hline 1 & UV & 3 & 23.2 & 37.3 & 1.27 & 0.79 \\
\hline
\end{tabular}




\section{Conclusions}

The surface roughness of the sanded specimens and the power consumption strongly depends on the grit size used. Overall power consumption increased with the decrease of grit size diameter, and all roughness parameters were found sensitive to the grit size. To obtain better glossiness values, the UV-cured varnish was preferred to the water-based product, while in terms of adherence, small differences were found between the two varnish products. The coating performance was significantly influenced by the varnish type ( $p$-value $\leq 0.05$ ). The sanding with a grit sequence of 60,120 , and 150 grit size abrasives was found to be optimal when applied to black alder wood, and it is recommended to obtain performant UV-coated wood surfaces for furniture products. This work was carried out for black alder wood, an under-utilized species that could have potential as a raw material for the manufacture value-added furniture units.

Acknowledgments: The authors would like to thank for the support received from Transilvania University of Brasov in Romania, the Division of Gluing and Finishing of Wood from the Faculty of Wood Technology in Poznan, and Remmers Company in Poland.

Author Contributions: Emilia-Adela Salca and Tomasz Krystofiak conceived and designed the experiments; Emilia-Adela Salca, Tomasz Krystofiak and Barbara Lis performed the experiments and they analyzed the data; Emilia-Adela Salca wrote the paper.

Conflicts of Interest: The authors declare no conflict of interest.

\section{References}

1. European Commission Home Page. Available online: https:/ / ec.europa.eu/jrc/en (accessed on 14 August 2017).

2. Marschner, S.R.; Westin, S.H.; Arbree, A.; Moon, J.T. Measuring and modeling the appearance of finished wood. In Proceedings of the SIGGRAPH, Los Angeles, CA, USA, 31 July-4 August 2005; pp. 727-734.

3. Varasquim, F.M.F.; Alves, M.C.; Goncalves, M.T.T.; Santiago, L.F.; Souza, A.J.D. Influence of belt speed, grit sizes and pressure on the sanding of Eucalyptus grandis wood. CERNE Lavras 2012, 18, $231-237$. [CrossRef]

4. Javorek, L.; Kúdela, J.; Svoreň, J.; Krajçoviçová, M. The influence of some factors on cutting force and surface roughness of wood after sanding. ProLigno 2015, 11, 516-524.

5. Demirkir, C.; Aydin, I.; Çolak, S.; Çolakoğlu, G. Effects of plasma treatment and sanding process on surface roughness of wood veneers. Turk. J. Agric. For. 2014, 38, 663-667. [CrossRef]

6. Sofuoglu, D.; Kurtoglu, A. Effects on machining conditions on surface roughness in planing and sanding of solid wood. Drv. Ind. 2015, 66, 265-272. [CrossRef]

7. Gurau, L.; Irle, M. Surface Roughness Evaluation Methods for Wood Products: A Review. Curr. For. Rep. 2017, 3, 119. [CrossRef]

8. Kilic, M.; Hoziroglu, S.; Burdurlu, E. Effect of machining on surface roughness of wood. Build. Environ. 2006, 41, 1074-1107. [CrossRef]

9. Malkocoglu, A. Machining properties and surface roughness of various wood species planed in different conditions. Build. Environ. 2007, 42, 2562-2567. [CrossRef]

10. Sandak, J.; Goli, G.; Cetera, P.; Sandak, A.; Cavalli, A.; Todaro, L. Machinability of minor wooden species before and after modification with thermos-vacuum tehnology. Materials 2017, 10, 121. [CrossRef] [PubMed]

11. Varanda, L.D.; Alves, M.C.S.; Goncalves, M.T.T.; Santiago, L.F.F. Influência das varáveis no lixamento tubular na qualidade das peças de Eucalyptus grandis. CERNE Lavras 2010, 16, $23-32$.

12. Jaic, M.; Palija, T.; Đorđević, M. The Impact of Surface Preparation of Wood on the Adhesion of Certain Types of Coatings. Zastita Mater. 2014, 55, 163-169. [CrossRef]

13. Ugulino, B.; Hernandez, R.E. Assessment of surface properties and solvent-borne coating performance of red oak wood produced by peripheral planning. Eur. J. Wood Prod. 2017, 75, 581-593. [CrossRef]

14. Landry, V.; Blanchet, P.; Cormier, L.M. Water-based and solvent-based stains: Impact on the grain raising in yellow birch. BioResources 2013, 8, 1997-2009. Available online: http:/ / ojs.cnr.ncsu.edu/index.php/BioRes/ article/view/BioRes_08_2_1997_Landry_Water_Solvent_Stains (accessed on 31 August 2017). [CrossRef] 
15. Sönmez, A.; Budakçı, M.; Pelit, H. The effect of the moisture content of wood on the layer performance of water-borne varnishes. BioResources 2011, 6, 3166-3177. Available online: http://ojs.cnr.ncsu.edu/ index.php/BioRes/article/view/BioRes_06_3_3166_sonmez_BP_Moisture_Wood_Varnishes (accessed on 31 August 2017).

16. Nejad, M.; Shafaghi, R.; Ali, H.; Cooper, P. Coating perfomance on oil-heat treated wood for flooring. BioResources 2013, 8, 1881-1892. Available online: http:/ / ojs.cnr.ncsu.edu/index.php/BioRes/article/view/ BioRes_08_2_1881_Nejad_Coating_Performance_Flooring (accessed on 31 August 2017). [CrossRef]

17. Cakicier, N.; Korkut, S.; Korkut, D. Varnish layer hardness, scratch resistance, and glossiness of various wood species as affected by heat treatment. BioResources 2011, 6, 1648-1658. Available online: http:/ / ojs.cnr.ncsu.edu/index.php/BioRes/article/view/BioRes_06_2_1648_Cakicier_KS_Varnish_ Hardness_Scratch_Heat_Treat (accessed on 31 August 2017).

18. Slabejova, G.; Smidriakova, M. Gloss of transparent coating on beech wood surface. Acta Fac. Xylol. 2016, 58, 37-44. [CrossRef]

19. Saeed, A.; Shabir, G. Synthesis of thermally stable high gloss water dispersible polyurethane/polyacrylate resins. Prog. Org. Coat. 2013, 76, 1135-1143. [CrossRef]

20. Philipp, C. The future of wood coatings. Eur. Coat. J. 2010, 1, 1-6.

21. Evans, P.D.; Haase, J.G.; Shakri, A.; Seman, B.M.; Kiguchi, M. The Search for Durable Exterior Clear Coatings for Wood. Coatings 2015, 5, 830-864. [CrossRef]

22. Nejad, M.; Shafaghi, R.; Pershin, L.; Mostaghimi, J.; Cooper, P. Thermal spray coating: A new way of protecting wood. BioResources 2017, 12, 143-156. Available online: http://ojs.cnr.ncsu.edu/index.php/ BioRes/article/view/BioRes_12_1_143_Nejad_Thermal_Spray_Coating_Protecting_Wood (accessed on 31 August 2017). [CrossRef]

23. Bulian, F.; Collavini, F.; Matellon, A. Investigating the Effects of Weathering on Wood Coatings. FME Trans. 2017, 45, 405-411. [CrossRef]

24. Budakçı, M.; Sönmez, A.; Pelit, H. The color changing effect of the moisture content of wood materials on water borne varnishes. BioResources 2012, 7, 5448-5459. Available online: http:/ / ojs.cnr.ncsu.edu/index. php/BioRes/article/view/BioRes_07_4_5448_Budakci_Color_Moisture_Content_Varnish (accessed on 31 August 2017). [CrossRef]

25. Salca, E.A.; Krystofiak, T.; Lis, B.; Mazela, B.; Proszyk, S. Some coating properties of black alder wood as function of varnish type and applications method. BioResources 2016, 11, 7580-7594. Available online: http: / / ojs.cnr.ncsu.edu/index.php/BioRes/article/view /BioRes_11_3_7580_Salca_Coating_Properties_ Black_Alder_Wood (accessed on 31 August 2017). [CrossRef]

26. Gurleyen, L.; Ayata, U.; Esteves, B.; Cakicier, N. Effects of heat treatment on the adhesion strength, pendulum hardness, surface roughness, color and glossiness of Scots pine laminated parquet with two different types of UV varnish application. Maderas Cienc. Tecnol. 2017, 19, 213-224. [CrossRef]

27. APMR—Asociaţia Producătorilor de Mobilă din România Home Page. Available online: http://www. industriamobilei.ro/cele-mai-mari-destinatii-de-export-pentru-mobila-romaneasca-2016 (accessed on 1 August 2017).

28. ISO 4287 (1998) Geometrical Product Specification (GPS)—Surface Texture: Profile Method-Terms, Definitions and Surface Texture Parameters; International Organization for Standardization: Geneva, Switzerland, 1998.

29. ISO 13565-2 (1996) Geometrical Product Specification (GPS)—Surface Texture: PROFILE Method; Surfaces Having Stratified Functional Properties_Part 2: Height Characterization Using the Linear Material Ratio Curve; International Organization for Standardization: Geneva, Switzerland, 1996.

30. Gurau, L.; Mansfield, H.; Irle, M. Processing Roughness of Sanded Wood Surfaces. Holz Roh-Werkst. 2005, 63, 43-52. [CrossRef]

31. DIN 53211 (1974) Testing of Paints, Varnishes and Similar Products. Determination of the Flow Time by the DIN 4 Cup; German Institute for Standardization: Berlin, Germany, 1974.

32. Paprzycki, O.; Proszyk, S.; Przybylak, A. Materials for The Exercises from The Technologies of The Finishing of Wood and Wood Based Materials Surfaces; Agriculture Academy: Poznan, Poland, 1985; p. 141. (In Polish)

33. ISO 4624 (2003) Paints, Varnishes and Plastics. Pull-Off Test for Adhesion; German Institute for Standardization: Berlin, Germany, 2003.

34. ISO 2813 (2014) Paints and Varnishes-Determination of Gloss Value at 20 Degrees, 60 Degrees and 85 Degrees; International Organization for Standardization: Geneva, Switzerland, 2014. 
35. De Moura, L.F.; Hernandez, R.E. Effects of abrasive mineral, grit size and feed speed on the quality of sanded surfaces of sugar maple wood. Wood Sci. Technol. 2006, 40, 517-530. [CrossRef]

36. Vitosyte, J.; Ukvalbergiene, K.; Keturakis, G. The effects of surface roughness on adhesion strength of coated ash (Fraxinus excelsior L.) and birch (Betula L.) wood. J. Mater. Sci. 2012, 18, 347-351. [CrossRef]

37. Wulf, M.; Netuschil, P.; Hora, G.; Schmich, P.; Cammenga, H.K. Investigation of the wetting characteristics of medium density fibreboards MDF by means of contact angle measurements. Holz Roh-Werkst. 1997, 55, 331-335. [CrossRef]

38. De Meijer, M.; Thurich, K.; Militz, H. Comparative study on penetration characteristics of modern wood coatings. Wood Sci. Technol. 1998, 32, 347-365. [CrossRef]

39. Demirci, Z.; Sonmez, A.; Budakci, M. Effect of thermal ageing on the gloss and adhesion strength of the wood varnish layers. BioResources 2013, 8, 1852-1867. Available online: http:/ / ojs.cnr.ncsu.edu/index. php/BioRes/article/view /BioRes_08_2_1852_Demirci_Thermal_Ageing_Gloss_Adhesion (accessed on 31 August 2017). [CrossRef]

40. Bekhta, P.; Proszyk, S.; Lis, B.; Krystofiak, T. Gloss of thermally densified alder (Alnus glutinosa Goertn.), beech (Fagus sylvatica L.), birch (Betula verrucosa Ehrh.), and pine (Pinus sylvestris L.) wood veneers. Eur. J. Wood Wood Prod. 2014, 72, 799-808. [CrossRef]

(C) 2017 by the authors. Licensee MDPI, Basel, Switzerland. This article is an open access article distributed under the terms and conditions of the Creative Commons Attribution (CC BY) license (http://creativecommons.org/licenses/by/4.0/). 